\title{
7. LATE PLIOCENE AND QUATERNARY PALEOCEANOGRAPHY OF THE CANARY ISLAND REGION INFERRED FROM PLANKTONIC FORAMINIFER ASSEMBLAGES OF SITE 9531
}

\author{
Charlotte A. Brunner ${ }^{2}$ and R. Maniscalco ${ }^{3}$
}

\begin{abstract}
Oceanic climatic conditions in the Canary Islands were strongly related to conditions in the high-latitude North Atlantic Ocean throughout the last 3.6 m.y. We examined relative frequencies of planktonic foraminifers sampled from pelagic and hemipelagic units of the late Pliocene and Quaternary intervals of Site 953. Assemblages were defined using cluster analysis. Assemblages alternated between cool and warmer subtropical types during the Gauss Chron, with one cool event centered at 3.3 Ma. Assemblages shifted abruptly to transitional types in the Matuyama and Brunhes Chrons. The shift, which began at $2.73 \mathrm{Ma}$, was marked by several apparent fluctuations between warmer and cooler assemblages culminating in a very rapid shift to a cool transitional assemblage at $2.5 \mathrm{Ma}$. Assemblages throughout the upper sequence alternated between cooler and warmer transitional types with a distinct change at $1.1 \mathrm{Ma}$ to assemblages that were either slightly less well preserved or slightly cooler than those of the early Quaternary. The changes in assemblages coincided not only with assemblage changes at a higher latitude in the North Atlantic Ocean, but also with increasing aridity in the North Sahara region. Both events were connected to increased intensity of the northeast trade winds. The excellent stratigraphic record recovered at Leg 157 sites in the volcanic apron of Gran Canaria clearly ties various phases of island evolution to regional paleoclimatic history.
\end{abstract}

\section{INTRODUCTION}

The volcanic apron of Gran Canaria is built of volcaniclastic turbidites, ash falls, debris flows, slumps, and lapilli slides, and holds a geologic history of island growth in a mid-plate setting near the African continental margin. The distal edge of the apron is also interlayered with pelagic units, which are relatively complete throughout the late Pliocene and Quaternary at Site 953. The apron thus holds not only information about the island's growth, but also information about its oceanic climatic history, which is relevant to the subaerial weathering history of Gran Canaria.

The Canary Islands at present lie within the northeast trade winds. The Gran Canaria lowlands are arid in climate with only $211 \mathrm{~mm}$ of precipitation annually recorded at Las Palmas on the windward side of the island (Lebedev, 1970). The uplands are covered by grasses, shrubs, and patches of pine forest at high elevations. The windward side of the island is moister than the barren, leeward side and is the center of island agriculture. During most of the previous glacial cycle, the climate was more arid than at present and, briefly during parts of oxygen isotope Stages 3 and 1, somewhat moister than at present as indicated by marine pollen records, marine eolian and carbonate records, and eolianite and paleosol sequences (Rognon et al., 1989; Hooghiemstra et al., 1992; Magarita and Jahn, 1992; Matthewson et al., 1995; Damnati et al., 1996). Arid periods correspond to strong northeast trade winds, as at the last glacial maximum, $\sim 18 \mathrm{ka}$, whereas moist conditions occur when the trade winds weaken, permitting greater rainfall from zonal winds, as at the Holocene climatic optimum 6 ka (Gardner and Hays, 1976; Sarnthein et al., 1981; Rognon et al., 1989). Gran Canaria has endured a minimal amount of subaerial river erosion as long as arid climate has dominated the region.

Our data address issues related to climate on Gran Canaria. We will show that surface waters of the region are linked to climatic forces from the high-latitude North Atlantic Ocean. The region at

${ }^{1}$ Weaver, P.P.E., Schmincke, H.-U., Firth, J.V., and Duffield, W. (Eds.), 1998. Proc. ODP, Sci. Results, 157: College Station, TX (Ocean Drilling Program).

${ }^{2}$ Institute of Marine Sciences, University of Southern Mississippi, John C. Stennis Space Center, MS 39529, U.S.A. cbrunner@whale.st.usm.edu

${ }^{3}$ Instituto di Geologia e Geofisica, Universitá di Catania, Corso, Italia 55, 95129 Catania, Italy. $\sim 2.8$ to $2.5 \mathrm{Ma}$ and $\sim 1$ Ma responded to intensification of the northeast trade winds, which are associated with north Saharan aridity. The data also suggest that conditions were distinctly different before 2.5 $\mathrm{Ma}$, which might mark the end of more humid conditions and the onset of aridity known from the North Sahara (Sarnthein et al., 1982; Stein, 1985; Tiedemann et al., 1989; Le Houerou, 1992; Morel, 1992).

\section{LOCALITY}

Site 953, the focus of this study, is located on the distal north northeast edge of the Gran Canaria volcanic apron (Figs. 1,2) where it might also receive volcaniclastic material from neighboring Fuerteventura and Tenerife as well as from Gran Canaria (T. Funck, pers. comm., 1995). The apron extends into a small basin, which is bordered by Gran Canaria and Tenerife to the south, the East Canary Ridge to the east, and the Salvage Islands to the north. The basin empties into the Madeira Abyssal Plain to the west. The small basin, including Site 953, is bathymetrically isolated from turbiditic input from the nearby Moroccan shelf, except for a distant passage between Lanzarote and Conception Bank.

The islands lie within the path of the cool Canary Current, part of the eastern boundary current of the North Atlantic gyre (Sverdrup et al., 1947; Mittelstaedt, 1991). The current is relatively shallow, only several hundred meters deep, but deep enough to host most planktonic foraminifers. Surface water temperatures average between $18^{\circ}$ and $24^{\circ} \mathrm{C}$ (U.S. Naval Weather Service Detachment, 1976), and surface water salinities average between 36.5 and 37.0 in the Canary Island region (Van Camp et al., 1991). Conditions are similar to those found upstream from the Canary Islands in the Azores region and, to some degree, downstream toward the Cape Verde Islands (U.S. Naval Weather Service Detachment, 1976), although temperatures warm several degrees from north to south. The current is wind driven, and in the Canary region responds to intensity of the trade winds.

Local conditions affect mesoscale features in surface waters of the Canaries region. Upwelled North Atlantic central water, which is cool, has lower salinity, and is relatively nutrient poor compared to upwelled waters to the south, advects to the islands from Capes Yubi and Bojador in the summer, and reduces surface water temperature

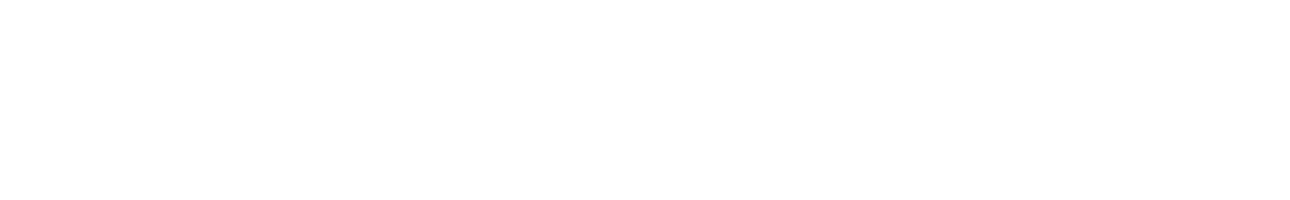


(Mittelstaedt, 1991; Van Camp et al., 1991; Hernandes-Guerra et al., 1993; Tomczak, 1982; Tomczak and Hughes, 1980). Passages between the island platforms disrupt the Canary Current, causing local upwelling of cool water and island wakes of warmer surface waters (Hernandes-Guerra et al., 1993). These local effects are wind driven and are controlled by the intensity of the trade winds as is the Canary Current in the Canary Island region.

Foraminifer assemblages in surface sediments reflect the location of the major surface water masses. In general, a transitional assemblage (in the sense of Tolderlund and Bé, 1971) follows the eastern boundary current from the Azores to the Canary Islands and southward. A cooler assemblage is found within the African coastal upwelling region, and a warmer subtropical fauna is found offshore from the Canary Islands in the stable interior of the southern Sargasso Sea (Crowley, 1981; Gardner and Hays, 1976; Corliss, 1975; Kipp,

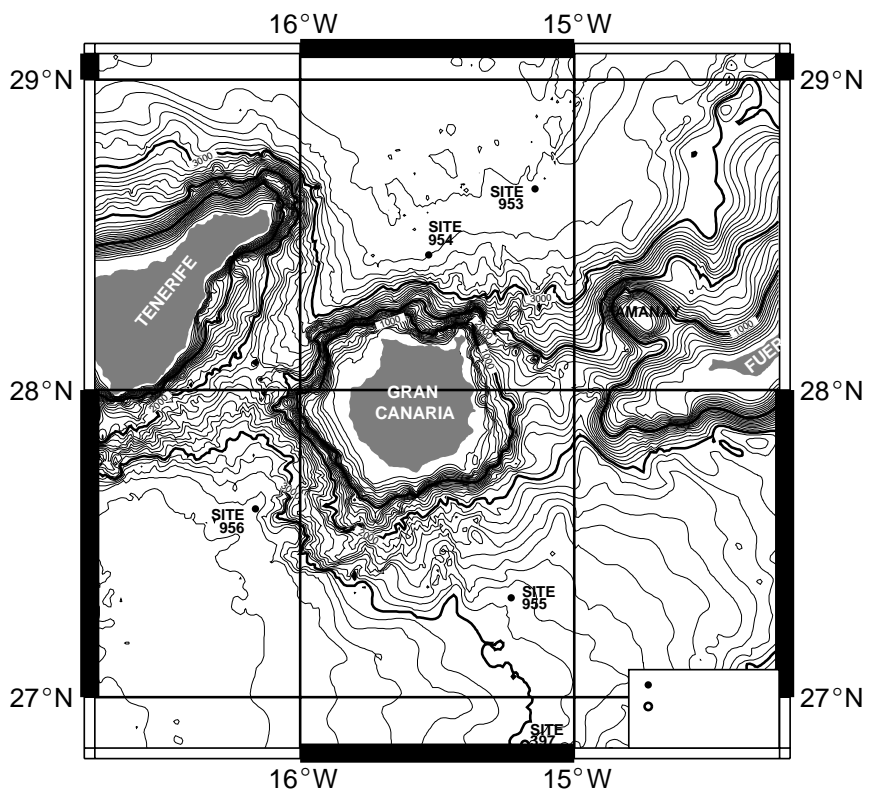

Figure 1. Locality map showing the location of Site 953 on the volcanic apron of Gran Canaria.
1976). During the late Quaternary, fossil assemblages in the Canary Current alternated between cool and warm transitional assemblages, and estimated sea surface temperature (SST) declined steadily by $4^{\circ}-$ $6^{\circ} \mathrm{C}$ in the Canary Island region from climatic optima to glacial maxima, then warmed rapidly, paralleling the sawtooth pattern of oxygen-isotope anomalies (Crowley, 1981).

\section{METHODS}

Samples from pelagic intervals were chosen from the late Pliocene and Quaternary turbiditic sequence of Site 953. We attempted to recover at least one sample from every section, but the distribution of turbidites, debris flows, and lapilli slides made sampling intervals larger than desired, especially in the upper Quaternary and lower upper Pliocene. The median interval was $1.71 \mathrm{~m}$, which was equivalent to $\sim 0.024 \mathrm{Ma}$. The $10-\mathrm{cm}^{3}$ samples were dried, soaked in a $1 \%$ Calgon solution, washed on a screen of $63-\mu \mathrm{m}$ openings, and dried. The sand-sized residue was further sieved at $150 \mu \mathrm{m}$ and split with a microsplitter until 300 or more specimens of planktonic foraminifers were separated for identification.

The upper Pliocene and Quaternary interval has fairly good time control constrained by 39 datum levels, including paleomagnetic reversals and first and last occurrences of planktonic foraminifers and calcareous nannofossils (Table 1). A simple age model to estimate sample ages was constructed by plotting a regression line through the datum levels as presented in Table 1 (Fig. 3). The model adequately summarized the datum levels as indicated by an $\mathrm{R}^{2}$ of 0.991 and a standard error of the estimate of \pm 0.093 m.y. The turbidites and other depositional events caused no large-scale hiatuses but, rather, produced overall constant sedimentation throughout this period (Fig. 3). However, undetected small-scale disconformities probably occur in the sequence, and interpretation of results, especially in detail, should be tempered by this uncertainty.

Eighteen counting groups of closely related taxa were defined as variables for calculating the cluster analysis. This was done to (1) reduce the number of variables (= species) because species diversity is high (68 taxa), (2) group together environmentally related taxa so the clusters respond more to climate change than to evolutionary changes, and (3) increase the abundances in each variable because the abundances for many individual species is quite low (Table 2).
Figure 2. Map showing the basin north of Gran Canaria, and the island ridges and sills that isolate it from turbiditic input from the adjacent African continental margin.

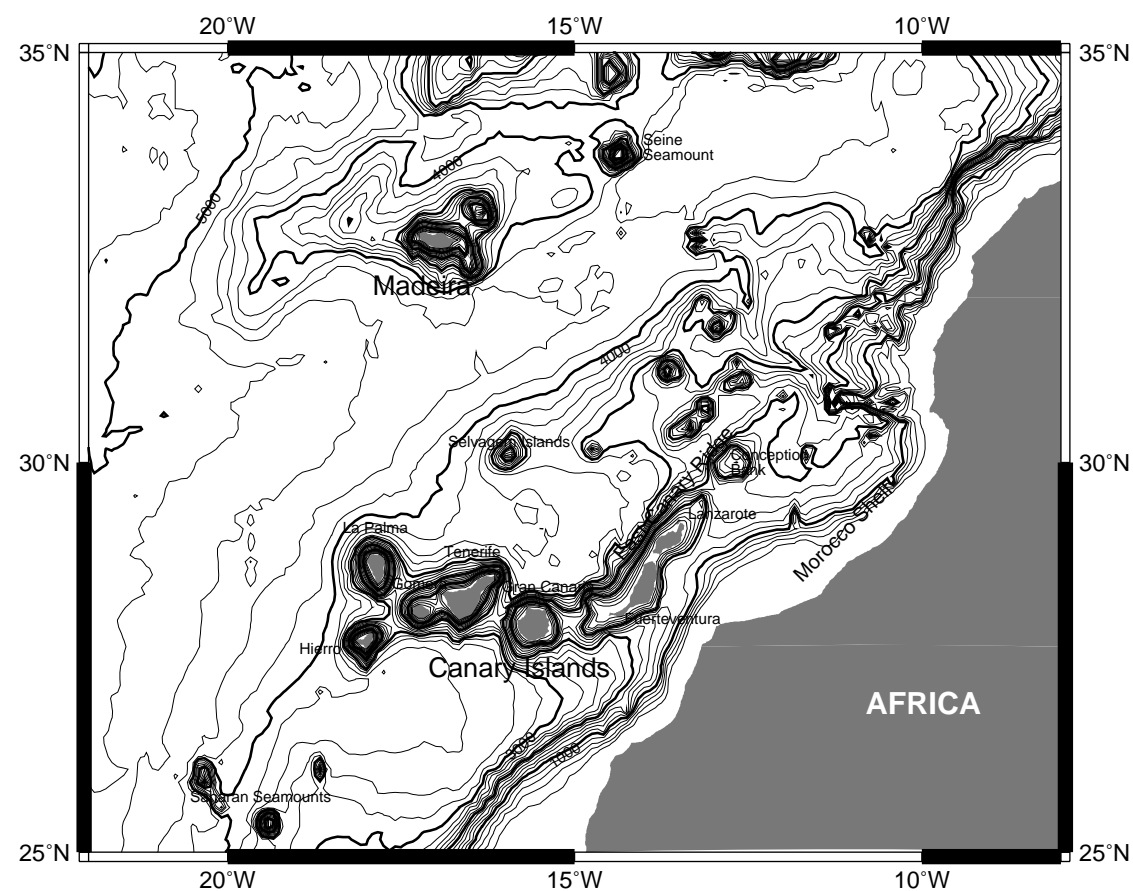


Table 1. Datum levels used in the age model to estimate sample ages.

\begin{tabular}{|c|c|c|c|}
\hline Datum level & $\begin{array}{l}\text { Depth } \\
\text { (mbsf) }\end{array}$ & $\begin{array}{l}\text { Age } \\
\text { (Ma) }\end{array}$ & $\begin{array}{c}\text { Estimated } \\
\text { age }\end{array}$ \\
\hline FO Gg. calida calida & 0.00 & 0.22 & 0.15 \\
\hline FO Gg. calida calida & 1.30 & 0.22 & 0.17 \\
\hline FO Gr. hirsuta tropical form & 28.96 & 0.45 & 0.55 \\
\hline FO Gr. hirsuta tropical form & 33.48 & 0.45 & 0.62 \\
\hline LO $P$. lacunosa & 15.63 & 0.46 & 0.37 \\
\hline LO P. lacunosa & 16.98 & 0.46 & 0.38 \\
\hline LO Gr. tosaensis & 36.10 & 0.65 & 0.65 \\
\hline LO Gr. tosaensis & 36.21 & 0.65 & 0.65 \\
\hline FO pink $G n$. ruber & 43.71 & 0.76 & 0.76 \\
\hline FO pink Gn. ruber & 44.35 & 0.76 & 0.77 \\
\hline Brunhes/Matuyama & 41.10 & 0.78 & 0.72 \\
\hline Brunhes/Matuyama & 41.30 & 0.78 & 0.72 \\
\hline Jaramillo $(\mathrm{t})$ & 59.80 & 0.99 & 0.98 \\
\hline Jaramillo (t) & 60.30 & 0.99 & 0.99 \\
\hline Jaramillo (o) & 65.30 & 1.07 & 1.06 \\
\hline Jaramillo (o) & 68.00 & 1.07 & 1.10 \\
\hline Cobb Mountain (t) & 75.30 & 1.20 & 1.20 \\
\hline Cobb Mountain (t) & 75.70 & 1.20 & 1.21 \\
\hline Cobb Mountain (o) & 77.90 & 1.21 & 1.24 \\
\hline Cobb Mountain (o) & 78.00 & 1.21 & 1.24 \\
\hline LO H. sellii & 72.90 & 1.22 & 1.17 \\
\hline LO H. sellii & 74.49 & 1.22 & 1.19 \\
\hline LO large Gephyrocapsa $>5.5 \mu \mathrm{m}$ & 78.96 & 1.22 & 1.25 \\
\hline LO large Gephyrocapsa $>5.5 \mu \mathrm{m}$ & 80.98 & 1.24 & 1.28 \\
\hline FO large Gephyrocapsa $>5.5 \mu \mathrm{m}$ & 95.29 & 1.46 & 1.48 \\
\hline FO large Gephyrocapsa $>5.5 \mu \mathrm{m}$ & 95.30 & 1.48 & 1.48 \\
\hline LO common C. macintyrei & 100.37 & 1.59 & 1.55 \\
\hline LO common C. macintyrei & 101.33 & 1.59 & 1.56 \\
\hline FO Gephyrocapsa spp. $>4.0 \mu \mathrm{m}$ & 100.37 & 1.67 & 1.55 \\
\hline FO Gephyrocapsa spp. $>4.0 \mu \mathrm{m}$ & 101.33 & 1.70 & 1.56 \\
\hline Olduvai $(\mathrm{t})$ & 100.60 & 1.77 & 1.55 \\
\hline Olduvai $(\mathrm{t})$ & 100.80 & 1.77 & 1.56 \\
\hline LO Gn. extremus & 125.94 & 1.77 & 1.91 \\
\hline LO Gn. extremus & 127.12 & 1.77 & 1.92 \\
\hline LO D. brouweri & 126.74 & 1.95 & 1.92 \\
\hline LO D. brouweri & 128.27 & 1.95 & 1.94 \\
\hline LO $D$. triradiatus & 131.61 & 1.95 & 1.99 \\
\hline LO D. triradiatus & 133.34 & 1.95 & 2.01 \\
\hline Olduvai (o) & 135.00 & 1.95 & 2.03 \\
\hline Olduvai (o) & 136.60 & 1.95 & 2.06 \\
\hline FO Gr. truncatulinoides & 140.56 & 2.00 & 2.11 \\
\hline FO Gr truncatulinoides & 140.95 & 2.00 & 2.12 \\
\hline Reunion $(\mathrm{t})$ & 145.80 & 2.14 & 2.19 \\
\hline Reunion $(\mathrm{t})$ & 146.00 & 2.14 & 2.19 \\
\hline Reunion (o) & 146.60 & 2.15 & 2.20 \\
\hline Reunion (o) & 146.80 & 2.15 & 2.20 \\
\hline LO Gr. exilis & 151.65 & 2.15 & 2.27 \\
\hline LO Gr. exilis & 154.49 & 2.15 & 2.31 \\
\hline Reappearance of Pulleniatina & 154.49 & 2.30 & 2.31 \\
\hline Reappearance of Pulleniatina & 154.71 & 2.30 & 2.31 \\
\hline LO Gr. miocenica & 154.71 & 2.30 & 2.31 \\
\hline LO Gr. miocenica & 157.79 & 2.30 & 2.35 \\
\hline $\mathrm{C} 2 \mathrm{r} .2 \mathrm{n}(\mathrm{t})$ & 169.40 & 2.42 & 2.52 \\
\hline $\mathrm{C} 2 \mathrm{r} .2 \mathrm{n}(\mathrm{t})$ & 169.60 & 2.42 & 2.52 \\
\hline C2r.2n (o) & 172.80 & 2.44 & 2.56 \\
\hline C2r.2n (o) & 174.40 & 2.44 & 2.59 \\
\hline Gauss/Matuyama & 177.60 & 2.60 & 2.63 \\
\hline Gauss/Matuyama & 177.70 & 2.60 & 2.63 \\
\hline LO D. tamalis & 176.84 & 2.78 & 2.62 \\
\hline LO D. tamalis & 178.70 & 2.78 & 2.65 \\
\hline Kaena (t) & 216.20 & 3.04 & 3.17 \\
\hline Kaena (t) & 216.30 & 3.04 & 3.17 \\
\hline LO Gr. mulitcamerata & 200.25 & 3.09 & 2.95 \\
\hline LO Gr. mulitcamerata & 206.47 & 3.09 & 3.03 \\
\hline LO D. altispira & 206.47 & 3.09 & 3.03 \\
\hline LO D. altispira & 207.41 & 3.09 & 3.05 \\
\hline LO Ss. seminulina & 207.96 & 3.12 & 3.05 \\
\hline LO Ss. seminulina & 216.28 & 3.12 & 3.17 \\
\hline FO Sa. dehiscens & 207.41 & 3.25 & 3.05 \\
\hline FO Sa. dehiscens & 207.96 & 3.25 & 3.05 \\
\hline Mammoth (o) & 226.20 & 3.33 & 3.31 \\
\hline Mammoth (o) & 235.10 & 3.33 & 3.43 \\
\hline LO Gr. margaritae & 236.24 & 3.58 & 3.45 \\
\hline LO Gr. margaritae & 245.10 & 3.58 & 3.57 \\
\hline Gauss/Gilbert & 244.80 & 3.59 & 3.57 \\
\hline Gauss/Gilbert & 244.90 & 3.59 & 3.57 \\
\hline Sphenolithus spp. & 236.23 & 3.60 & 3.45 \\
\hline Sphenolithus spp. & 245.11 & 3.60 & 3.57 \\
\hline
\end{tabular}

Notes: The nannofossil data is from Sblendorio-Levy and Howe (Chap. 8, this volume), and the foraminifer data is from Maniscalco and Brunner (Chap. 10, this volume). The polarity shifts are unpublished (B. Herr and M. Fuller, pers. comm., 1996). The time scale is that from Berggren et al. (1995). FO = first occurrence, LO = last occurrence, $\mathrm{o}=$ onset, and $\mathrm{t}=$ termination.
Q-mode cluster analysis grouped together samples with similar assemblages. We used a simple Euclidean distance coefficient and agglomerated samples using within-group average linkage (Norusis, 1988). The species counts were normalized to percentages within samples before computation of the clusters. The faunal compositions of clusters were determined by calculating the average and standard deviation of each taxon in each cluster of samples.

\section{THE FAUNA}

The faunal succession at Site 953 is controlled by an interaction among three controls: evolutionary events, climate change, and carbonate dissolution. The fauna consists of more than 60 species and is best characterized as transitional (Tolderlund and Bé, 1971) through most of the Matuyama and Brunhes sequences and subtropical in the Gauss interval below 177.6 meters below seafloor (mbsf; Table 3 on $\mathrm{CD}-\mathrm{ROM}$ in the back pocket of this volume). Cool species of Neogloboquadrina dominate the Brunhes and Matuyama faunas, followed by Globigerina, Globigerinita, Globigerinoides, Globoconella, and Hirsutella (Fig. 4). By contrast, all of these groups are less important in the Gauss assemblage except for Globigerinita, which increases in abundance. Menardella is more abundant than in the overlying sequences, and Zeaglobigerina equals Globigerinita in abundance.

Several faunal fluctuations are worthy of particular notice (Fig. 4). Percentages of Globoconella, specifically Globorotalia puncticulata and Globorotalia inflata, plunge to near zero in two latest Pliocene intervals centered at $\sim 226$ and $154 \mathrm{mbsf}$ ( $\sim 3.3$ and $2.3 \mathrm{Ma}$, respectively), whereas cool species of Neogloboquadrina reach relative maxima. Globorotalia puncticulata, in fact, is extinguished at the upper event, and the Globoconella population nearly doubles above the upper event. Several faunal changes occur near the Pliocene/Pleistocene boundary, which lies between 104 and 127.13 mbsf (Maniscalco and Brunner, this volume). Globigerinoides obliquus becomes extinct (Berggren et al., 1995), Neogloboquadrina dutertrei peaks in abundance (Weaver, 1987), Globigerinella aequilateralis increases in abundance and remains near $5 \%$ of the assemblage throughout the Quaternary, whereas Globorotalia crassaformis and warm-water taxa of Neogloboquadrina become minor components of the Quaternary assemblage. One other faunal change is important in the Quaternary interval. Globorotalia truncatulinoides, dominated by the right coiling form, increases from $\sim 1 \%$ of the assemblage in the lower Pleistocene to $5 \%$ on average above $82 \mathrm{mbsf}(\sim 1.29 \mathrm{Ma})$.

\section{CLUSTER ANALYSIS}

The cluster analysis separated samples into three major groups that were further divided into seven subgroups (Fig. 5). Five taxa are abundant in the assemblages of cluster 1, Neogloboquadrina pachyderma, Globigerinita glutinata, Globigerinoides ruber, Globoconella, and Globigerina (Fig. 6). Neogloboquadrina pachyderma dominates the assemblages comprising $>30 \%$ of the fauna in cluster $1 \mathrm{~b}$ and almost $40 \%$ of the fauna in cluster 1a. These relationships suggest that cluster 1 is a cool transitional association of species (Tolderlund and Bé, 1971; Kipp, 1976). The enrichment of Nq. pachyder$m a$ and depletion of solution-susceptible Globigerinita glutinata in cluster 1a may be either a dissolution effect or surface-water cooling.

The same taxa that are important in cluster 1 are also important in cluster 2, but abundance is more equitably distributed and Globoconella, especially G. inflata, is distinctly more important (Fig. 6). The cluster $2 \mathrm{a}$ assemblage differs from that of cluster $2 \mathrm{~b}$ by having more $N$. pachyderma and Globoconella compared to the more solution susceptible taxa, Globigerinoides ruber and Globigerinita glutinata. Hence, cluster 2a seems to be either a slightly dissolved expression of the cluster $2 \mathrm{~b}$ assemblage or a slightly cooler assemblage. 
Figure 3. Age model calculated from the datum levels as listed in Table 1. The model is a regression line, $Y=$ $0.01398 * X+0.147031$, where $Y$ is the estimated age (Ma) and $X$ is the depth (mbsf). $\mathrm{R}^{2}=0.991$, and the standard error of the estimate is $0.092518 \mathrm{Ma}$. Notice that there are no major hiatuses, although there may be small interruptions to average sedimentation such as at 102 mbsf.

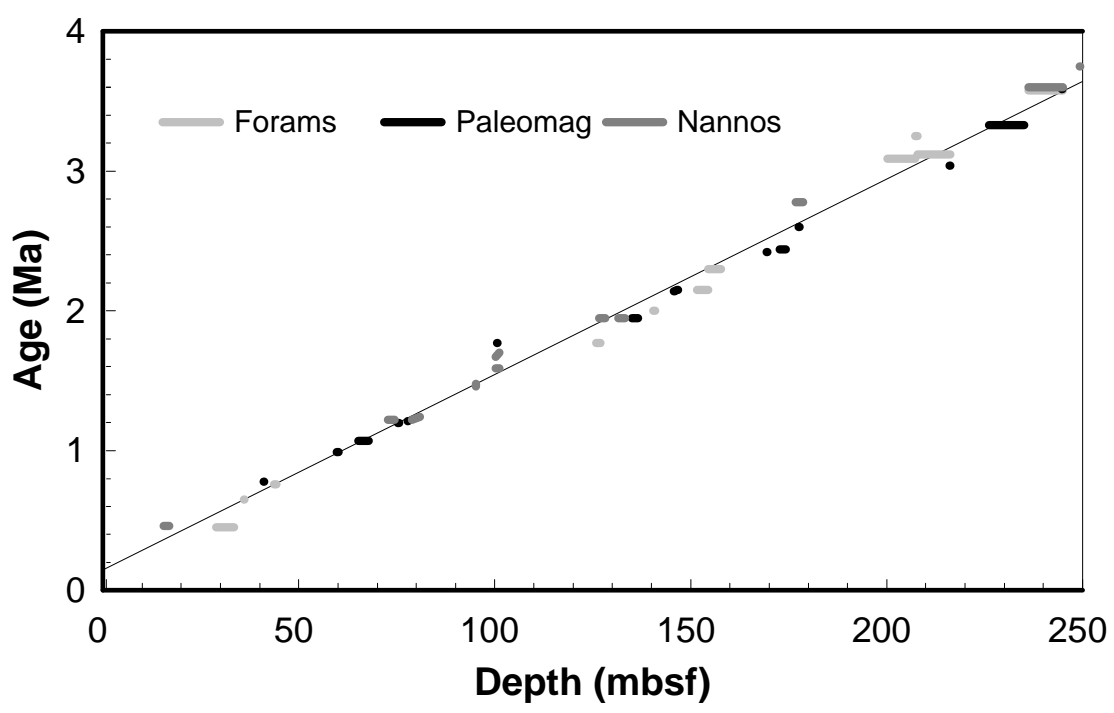

Samples in cluster 2c differ by an increase in the frequencies of Zeaglobigerina and Globigerina, the former being associated with the warmth and high salinity of subtropical water masses (Tolderlund and Bé, 1971; see Dowsett and Poore, 1990). It is the most subtropical of the transitional subcluster assemblages. The three assemblages are typical of a warm transitional association of species (Tolderlund and Bé, 1971; Kipp, 1976).

The assemblages of cluster 3 (Fig. 6) are distinct from those of clusters 1 and 2. Cluster 3 contains abundant Zeaglobigerina and Globigerinita with minor amounts of Globoconella, which distinguishes it from the cluster $2 \mathrm{c}$ assemblage. The cluster $3 \mathrm{a}$ and $3 \mathrm{~b}$ assemblages differ from one another in the importance of Neogloboquadrina species. Cluster 3a has more cool-water species of Neogloboquadrina, such as sinistral and dextral Neogloboquadrina pachyderma, whereas the assemblage of cluster $3 \mathrm{~b}$ has more warmwater species of Neogloboquadrina, like Nq. acostaensis, Nq. humerosa, and Nq. dutertrei. The cluster 3 assemblage is warmer than those of clusters 1 and 2, based on its greater species diversity, greater species equitability, and larger numbers of subtropical taxa (Table 3 on CD-ROM; Fig. 4). The assemblages are cool (cluster 3a) and warm (cluster 3b) subtropical.

\section{TIMING OF FAUNAL CHANGES}

The subtropical assemblage of cluster 3 dominates the samples of the Gauss Chron (Fig. 7). There is a cool interval from $\sim 3.43$ to 3.21 Ma (235.06-218.81 mbsf), when the cool subtropical assemblage of cluster $3 \mathrm{a}$ and the warm transitional assemblage of cluster $2 \mathrm{c}$ occur, followed by a return to warm subtropical conditions from 3.19 to 3.03 Ma (217.94-206.47 mbsf). Conditions fluctuate from 2.95 to 2.73 Ma (200.24-184.80 mbsf) between the cool and warm subtropical faunas of clusters $3 \mathrm{a}$ and $3 \mathrm{~b}$, then begin to shift to distinctly cooler faunas heralded by cool events at 2.69 and $2.61 \mathrm{Ma}$ (181.79 and $176.26 \mathrm{mbsf}$ ), when warm transitional faunas of clusters $2 \mathrm{a}$ and $2 \mathrm{c}$ appear. Assemblages become steadily cooler from 2.58 to $2.49 \mathrm{Ma}$ (174.18-167.82 mbsf), return briefly to the warm transitional fauna of cluster $2 \mathrm{c}$ at 2.40 and $2.38 \mathrm{Ma}$ (161.15 and $159.60 \mathrm{mbsf}$ ), and then return to the transitional faunas that characterize the remainder of the Pliocene and Quaternary.

The latest Pliocene and Quaternary faunas alternate between warm and cool transitional assemblages that may also be better and less well preserved. From 2.35 to $1.19 \mathrm{Ma}$ (157.79-74.51 mbsf), assemblages fluctuate between the cool and warm transitional faunas of clusters $1 b$ and $2 b$, with sporadic occurrences of the cool and warm transitional faunas of clusters 1a and 2a. Beginning at 1.11 Ma (68.73 mbsf), only one set of warm and cool transitional assemblages, 1a and $2 \mathrm{a}$, dominate the site. The upper Quaternary interval may be either cooler or more poorly preserved than that of the lower Quaternary. The sampling interval of available calcium carbonate data from Site 953 is too coarse to resolve preservation trends within the Quaternary sequence (Shipboard Scientific Party, 1995).

\section{COMPARISON TO OTHER SITES IN THE NORTH ATLANTIC OCEAN}

A similar sequence of Pliocene and Quaternary climatic events has been reported from the North Atlantic Ocean and African continental locales (deMenocal, 1995, and references therein). Faunal evidence from the North Atlantic Ocean, including estimates of SST, increased abundance of cool Neogloboquadrina, and the disappearance of warmer species like Globoconella, indicate a cool interval centered at 3.3 Ma (= "puncticulata gap" of Dowsett and Loubere, 1992; Dowsett and Poore, 1990, 1991; Raymo et al., 1987; Dowsett et al., 1988). The cool event falls within a warm interval from 4.0 to $\sim 3 \mathrm{Ma}$, when surface waters were warmer than those of the presentday at Sites 548, 552, 606, and 609 in the North Atlantic Ocean. The Pliocene warmth was terminated by a cooling (Dowsett and Loubere, 1992; Dowsett and Poore, 1990, 1991; Raymo et al., 1987; Dowsett et al., 1988; Tiedemann et al., 1994) that began at 2.9 Ma and culminated in a rapid decrease between 2.5 and $2.4 \mathrm{Ma}$, when ice rafted debris appeared in northerly cores (Backman, 1979; Zimmermann et al., 1984; Shackleton et al., 1990). Quaternary climate in the North Atlantic Ocean changed again in timing and intensity of glacial cycles at some point in the middle Pleistocene between 1.1 and $0.4 \mathrm{Ma}$, depending on the variables assessed (Ruddiman et al., 1989; Raymo et al., 1989). For example, Ruddiman et al. (1987), noted a change from warm to cooler SST at $\sim 1.05 \mathrm{Ma}$ at Site 607 near the Azores Islands. Ultimately, these events were caused by changes in climatic response at high and low latitudes to orbital periodicities (Hays et al., 1976; deMenocal, 1995; deMenocal et al., 1993; Tiedemann et al., 1994; Ruddiman et al., 1989; Raymo et al., 1989).

The climatic trends evident in the late Pliocene at Site 953 are similar in timing to those described above from higher latitudes in the North Atlantic Ocean, although there are some apparent discrepancies in detail that may be caused by differences in data analyses and slight differences in timescales and age models. At Site 953, between 3 and $2.58 \mathrm{Ma}$, we see a cycling between cool and warm subtropical assemblages with two intrusions of cool assemblages followed by a 
Table 2. Taxonomic composition of counting groups used in the cluster analysis.

\begin{tabular}{|c|c|}
\hline Counting group & Taxon \\
\hline Globoquadrina spp. & $\begin{array}{l}\text { Gq. altispira } \\
\text { Gq. venzuelana }\end{array}$ \\
\hline Globigerinella aequilateralis & Ge. aequilateralis \\
\hline Globigerinella spp. & $\begin{array}{l}\text { Ge. calida calida } \\
\text { Ge. calida praecalida } \\
\text { Ge. cf. calida praecalida } \\
\text { Ge. obesa } \\
\text { Ge. cf. obesa }\end{array}$ \\
\hline Globigerina spp. & $\begin{array}{l}\text { Gg. apertura } \\
\text { Gg. bulloides } \\
\text { Gg. cf. bulloides } \\
\text { Gg. eamesi }\end{array}$ \\
\hline Globigerina falconensis & Gg. falconensis \\
\hline Zeaglobigerina spp. & $\begin{array}{l}\text { Gg. rubescens } \\
\text { Gg. decoraperta } \\
\text { Gg. cf. druryi } \\
\text { Gg. woodi } \\
\text { Gg. cf. woodi }\end{array}$ \\
\hline Globoconella spp. & $\begin{array}{l}\text { Gr. inflata } \\
\text { Gr. puncticulata } \\
\text { Gr. cf. puncticulata }\end{array}$ \\
\hline Hirsutella spp. & $\begin{array}{l}\text { Gr. hirsuta } \\
\text { Gr. scitula } \\
\text { Gr. margaritae evoluta }\end{array}$ \\
\hline Menardella spp. & $\begin{array}{l}\text { Gr. exilis } \\
\text { Gr. cultrata } \\
\text { Gr. miocenica } \\
\text { Gr. cf. miocenica } \\
\text { Gr. pertenuis } \\
\text { Gr. cf. pseudomiocenica }\end{array}$ \\
\hline Globorotalia crassaformis Group & $\begin{array}{l}\text { Gr. crassaformis } \\
\text { Gr. crassula } \\
\text { Gr. ronda }\end{array}$ \\
\hline Truncorotalia spp. & $\begin{array}{l}\text { Gr. tosaensis } \\
\text { Gr. truncatulinoides }(\mathrm{dex}) \\
\text { Gr. truncatulinoides }(\sin )\end{array}$ \\
\hline Globigerinoides spp. A & $\begin{array}{l}\text { Gs. bolli } \\
\text { Gs. conglobatus } \\
\text { Gs. obliquus } \\
\text { Gs. obliquus extremus } \\
\text { Gs. obliquus obliquus } \\
\text { Gs. ruber } \\
\text { Gs. tenellus }\end{array}$ \\
\hline Globigerinoides spp. B & $\begin{array}{l}\text { Gs. trilobus } \\
\text { Gs. sacculifer }\end{array}$ \\
\hline Globigerinita spp. & $\begin{array}{l}\text { Gt. glutinata } \\
\text { Gt. iota } \\
\text { Gt. uvula }\end{array}$ \\
\hline Warm Neogloboquadrina spp. & $\begin{array}{l}\text { Nq. acostaensis }(\mathrm{dex}) \\
N q . \text { cf. acostaensis }(\mathrm{dex}) \\
\text { Nq. acostaensis }(\mathrm{sin}) \\
\text { Nq. dutertrei } \\
\text { Nq. cf. dutertrei } \\
\text { Nq. humerosa }\end{array}$ \\
\hline Cool Neogloboquadrina spp. & $\begin{array}{l}\text { Nq. pachyderma }(\mathrm{dex}) \\
N q . \text { cf. pachyderma }(\operatorname{dex}) \\
N q . \text { pachyderma }(\sin )\end{array}$ \\
\hline Sphaeroidinella and Sphaeroidinellopsis & $\begin{array}{l}\text { Sa. dehiscens } \\
\text { Ss. seminulina }\end{array}$ \\
\hline Orbulina universa & Or. universa \\
\hline
\end{tabular}

Note: Dex $=$ dextrally coiled specimens, and $\sin =$ sinistrally coiled specimens .

clear step to cooler conditions between 2.58 and 2.49 Ma. However, this pattern is not seen at Site 548 in the high-latitude North Atlantic, where paleotemperatures estimated from a transfer function decline steadily between 2.8 and $2.5 \mathrm{Ma}$, with a distinct step to cooler temperatures restricted from 2.5 to $2.4 \mathrm{Ma}$ (GSF18; Dowsett and Poore, 1990; Dowsett and Loubere, 1992). The cluster analysis that we used emphasized step-like changes and obscured continuous trends, so we suspect that differences in detail between our site and others in the North Atlantic Ocean might vanish with application of the same method (i.e., transfer function) and identical age models. We can say with confidence that assemblages at our latitude $\left(29^{\circ} \mathrm{N}\right)$ cool dramatically a short time before and during initial buildup of glacial ice at 2.4 Ma, inferred from oxygen-isotope data (Sikes et al., 1991; Shackleton et al., 1990; apply age model of Dowsett and Loubere, 1992).

We observed a distinct faunal change to more dissolved and/or cooler assemblages in the Quaternary at $\sim 1.11 \mathrm{Ma}$. Cooling of SST and a decrease in calcium carbonate also occur after 1.0 Ma at Site 607, which lies upstream from the Canary Islands (Ruddiman et al., 1987). A mid-Pleistocene transition in both the magnitude and rhythm of many variables, such as oxygen isotopes, percentage of calcium carbonate, SST (Ruddiman et al., 1989), and flux, composition and size of eolian dust (Sarnthein et al., 1982; Stein, 1985; Tiedemann et al., 1989), occurred between 1.1 and $0.4 \mathrm{Ma}$, depending on the variable considered and the location studied (Ruddiman et al., 1989). Our mid-Pleistocene event may precede these slightly, but is probably related to the same underlying change in dominance of orbital eccentricity over obliquity in modulation of North Atlantic climate (Ruddiman et al., 1989). Clearly, climate changes at the site are connected with climate changes at high latitude.

Our data show that the surficial waters surrounding Gran Canaria changed in synchrony with indicators of aridity known from the marine record, so it is reasonable to infer that climate on Gran Canaria followed the regional pattern. The water mass changes we infer from assemblage changes at $\sim 2.8$ Ma coincide with increased upwelling, inferred from increased rates of biogenic opal sedimentation, and increased eolian deposition, inferred from flux, composition, and the size of eolian dust (Sarnthein et al., 1982; Stein, 1985; Tiedemann et al., 1989), offshore from the northern Sahara. The water mass change we infer at 1.1 Ma coincides with an increase in eolian deposition between 1.1 and $0.7 \mathrm{Ma}$ at Site 659 (deMenocal, 1995; deMenocal et al., 1993; Tiedemann et al., 1989). All are connected to intensification of the northeast trade winds, which are driven by increased temperature gradients at high latitudes.

\section{CONCLUSIONS}

1. The Gauss subtropical assemblages of planktonic foraminifers differ markedly from the Matuyama and Brunhes transitional assemblages. They contain more Zeaglobigerina, Globigerinita, and Menardella and less Neogloboquadrina, Globigerina, Globigerinoides, Globoconella, and Hirsutella than the younger assemblages.

2. Q-mode cluster analysis agglomerated three groups of samples that are distinguished by three assemblages: a subtropical assemblage in cluster 3, a warm transitional assemblage in cluster 2, and a cool transitional assemblage in cluster 1. Each group is composed of two or three subgroups whose assemblages differ slightly probably because of differences in either temperature or post-depositional preservation. Cluster 3 characterizes the Gauss samples and is most different from the other two clusters based on the simple Euclidean distance coefficient.

3. The succession of assemblages at Site 953 shows a subtropical fauna in the Gauss, with a cooler transitional fauna in a short interval at $\sim 3.3 \mathrm{Ma}$. Faunas become progressive cooler between 3.0 and $2.38 \mathrm{Ma}$, with several apparent warming and cooling events imbedded in the general trend. Assemblages are transitional throughout the remainder of the Matuyama and the Quaternary, and alternate frequently between warmer and cooler transitional faunas. There is a change to slightly different transitional faunas after $\sim 1.1 \mathrm{Ma}$. 

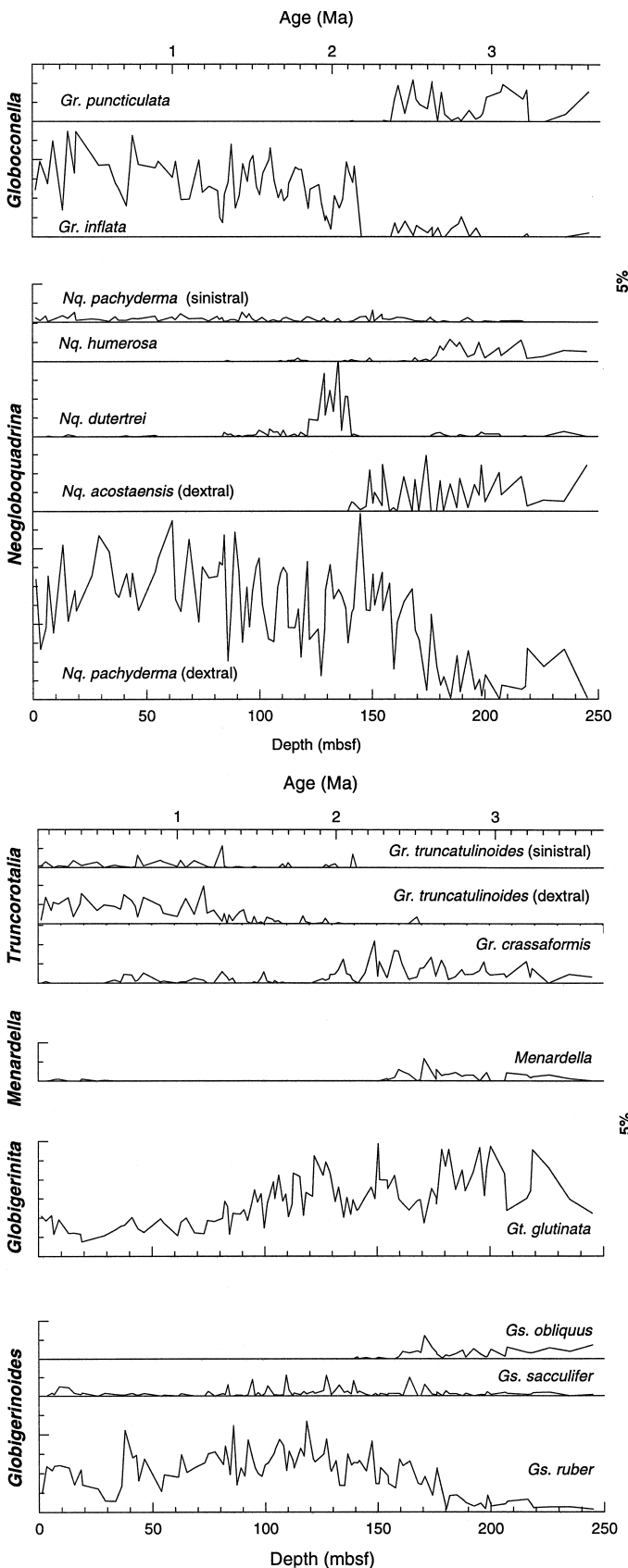
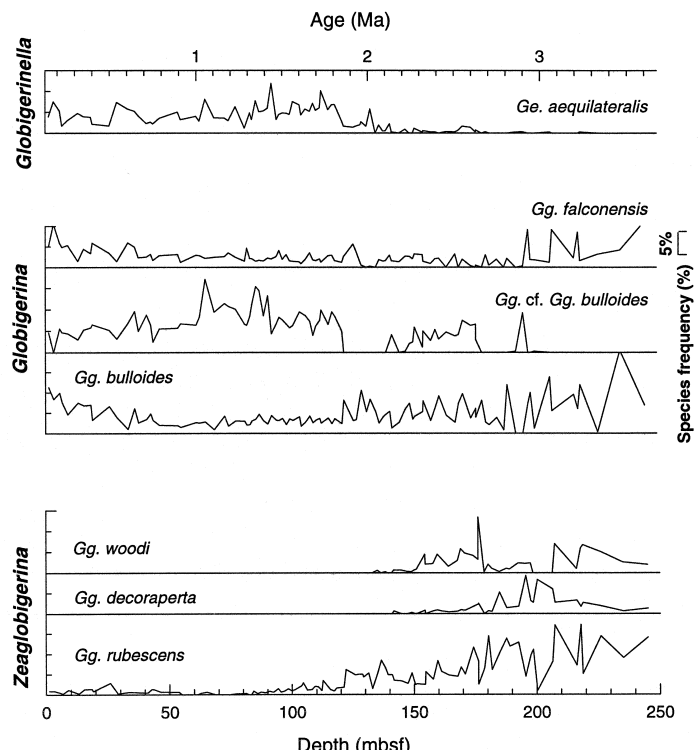

[0.

Figure 4. Percentages of important selected species plotted with depth in site.

4. The timing of faunal events near Gran Canaria matches that found in the higher latitude North Atlantic Ocean.

5. The timing of faunal events also coincides with upwelling and aridity indicators from the North African region, suggesting that Gran Canaria endured a climate that corresponds to that of the Northern Sahara and was likely more humid than at present during the Gauss and more arid during the Matuyama and Brunhes Chrons.

\section{ACKNOWLEDGMENTS}

The research was supported in part by a grant from the JOI U.S. Science Support Program to C. Brunner and a Consiglio Nazionale delle Ricerche grant to R. Maniscalco during her 1995-1996 stay at the Istututo di Geologic Marina, Consiglio Nazionale delle Ricerche, Bologna (Institute of Marine Sciences Contribution Number 0185).

\section{REFERENCES}

Backman, J., 1979. Pliocene biostratigraphy of DSDP Sites 111 and 116 from the North Atlantic Ocean and the age of Northern Hemisphere Glaciation. Stockholm Contrib. Geol., 32:115-137.

Berggren, W.A., Kent, D.V., Swisher, C.C., III, and Aubry, M.-P., 1995. A revised Cenozoic geochronology and chronostratigraphy. In Berggren, W.A., Kent, D.V., Aubry, M.-P., and Hardenbol, J. (Eds.), Geochronology, Time Scales and Global Stratigraphic Correlation. Spec. Publ.Soc. Econ. Paleontol. Mineral., 54:129-212.

Corliss, B.H., 1975. Late Pleistocene paleoclimatology: planktonic foraminiferal analysis of sediment cores from the central North Atlantic. Palaeogeogr., Palaeoclimatol., Palaeoecol., 18:45-61. 
Crowley, T.J., 1981. Temperature and circulation changes in the eastern North Atlantic during the last 150,000 years: evidence from the planktonic foraminfieral record. Mar. Micropaleontol., 6:97-129.

Damnati, B., Petit-Maire, N., Fontugne, M., Meco, J., and Williamson, D., 1996. Quaternary palaeoclimates in the eastern Canary Islands. Quat. Int., 31:37-46.

deMenocal, P.B., 1995. Plio-Pleistocene African climate. Science, 270:5359.

deMenocal, P.B., Ruddiman, W.F., and Pokras, E.M., 1993. Influence of high- and low-latitude on African terrestrial climate: Pleistocene eolian records from equatorial Atlantic Ocean Drilling Program Site 663. Paleoceanography, 8:209-242.

Dowsett, H.J., Gosnell, L.B., and Poore, R.Z., 1988. Pliocene planktic foraminifer census data from Deep Sea Drilling Project Holes 366A, 410, 606, and 646B. Open-File Rep.-U.S. Geol. Surv., 88-654:1-14.

Dowsett, H.J., and Loubere, P., 1992. High resolution late Pliocene sea-surface temperature record from the Northeast Atlantic Ocean. Mar. Micropaleontol., 20:91-105.

Dowsett, H.J., and Poore, R.Z., 1990. A new planktic foraminifer transfer function for estimating Pliocene-Holocene paleoceanographic conditions in the North Atlantic. Mar. Micropaleontol., 16:1-23.

1991. Pliocene sea surface temperatures of the North Atlantic Ocean at 3.0 Ma. In Cronin, T.M., and Dowsett, H.J. (Eds.), Pliocene Climates. Quat. Sci. Rev., 10:189-204.

Gardner, J.V., and Hays, J.D., 1976. Responses of sea-surface temperature and circulation to global climatic change during the past 200,000 years in the eastern equatorial Atlantic Ocean. In Cline, R.M., and Hays, J.D. (Eds.), Investigations of Late Quaternary Paleoceanography and Paleoclimatology. Mem.-Geol. Soc. Am., 145:221-246.

Hays, J.D., Imbrie, J., and Shackleton, N.J., 1976. Variations in the Earth's orbit: pacemaker of the ice ages. Science, 194:1121-1132.

Hernandes-Guerra, A., Aristigui, J., Canton, M., and Nykjaer, L., 1993. Phytoplankton pigment patterns in the Canary Islands area as determined using coastal zone colour scanner data. Int. J. Remote Sensing, 14:14311437.

Hooghiemstra, H., Stalling, H., Agwu, C.O.C., and Dupont, L.M., 1992. Vegetational and climatic changes at the northern fringe of the Sahara 250,000-5,000 years BP: evidence from 4 marine pollen records located between Portugal and the Canary Islands. Rev. Paleobot. Palynol., 74:153.

Kipp, N.G., 1976. New transfer function for estimating past sea-surface conditions from sea-bed distribution of planktonic foraminiferal assemblages in the north Atlantic. In Cline, R.M., and Hays, J.D. (Eds.), Investigation of Late Quaternary Paleoceanography and Paleoclimatology. Mem.Geol. Soc. Am., 145:3-41.

Lebedev, A.N., 1970. The Climate of Africa: Jerusalem (Israel Program for Scientific Translations)

Le Houerou, H.N., 1992. Ourline of the biological history of the Sahara. J. Arid Environ., 22:3-30.

Margarita, M., and John, R., 1992. Pleistocene and Holocene soil carbonates from Lanzarote, Canary Islands, Spain: paleoclimatic implications. Catena, 19:511-519.

Matthewson, A.P., Shimmield, G.B., Kroon, D., and Fallick, A.E., 1995. A $300 \mathrm{kyr}$ high-resolution aridity record of the North African continent. Paleoceanography, 10:677-692.

Mittelstaedt, E., 1991. The ocean boundary along the northwest African coast: circulation and oceanographic properties at the sea surface. Prog. Oceanogr., 26:307-355.

Morel, A., 1992. The disappearance of hot, humid climates south of the Sahara at the Pliocene-Quaternary boundary. Z. Geomorphol., 36:191205.

Norusis, M.J., 1988. SPSS/PC+Advanced Statistics TM V2.0 for the IBM PC/ $X T / A T$ and $P S / 2$ : Chicago (SPSS Inc.).

Raymo, M.E., Ruddiman, W.F., Backman, J., Clement, B.M., and Martinson, D.G., 1989. Late Pliocene variation in Northern Hemisphere ice sheets and North Atlantic deep water circulation. Paleoceanography, 4:413446.

Raymo, M.E., Ruddiman, W.F., and Clement, B.M., 1987. Pliocene-Pleistocene paleoceanography of the North Atlantic at DSDP Site 609. In Ruddiman, W.F., Kidd, R.B., Thomas, E., et al., Init. Repts. DSDP, 94 (Pt. 2): Washington (U.S. Govt. Printing Office), 895-901.

Rognon, P., Coude-Gaussen, G., Le Coustumer, M.-N., Balouet, J.C., and Occhietti, S., 1989. Le massif dunaire de Jandia (Fuerteventura, Canar- ies): evolution des paleoenvironnements de 20,000 BP a l'actuel. Bull. Assoc. Fr. Etude Quat., 37:31-37.

Ruddiman, W.F., McIntyre, A., and Raymo, M., 1987. Paleo-environmental results from North Atlantic Sites 607 and 609. In Ruddiman, W.F., Kidd, R.B., Thomas, E., et al., Init. Repts. DSDP, 94 (Pt. 2): Washington (U.S. Govt. Printing Office), 855-878.

Ruddiman, W.F., Raymo, M.E., Martinson, D.G., Clement, B.M., and Backman, J., 1989. Pleistocene evolution: Northern Hemisphere ice sheets and North Atlantic Ocean. Paleoceanography, 4:353-412.

Sarnthein, M., Tetzlaff, G., Koopmann, B., Wolter, K., and Pflaumann, U., 1981. Glacial and interglacial wind regimes over the eastern subtropical Atlantic and Northwest Africa. Nature, 293:193-196.

Sarnthein, M., Thiede, J., Pflaumann, U., Erlenkeuser, H., Fütterer, D., Koopmann, B., Lange, H., and Seibold, E., 1982. Atmospheric and oceanic circulation patterns off Northwest Africa during the past 25 million years. In von Rad, U., Hinz, K., Sarnthein, M., Seibold, E. (Eds.), Geology of the Northwest African Continental Margin: Berlin (Springer Verlag), 545-604.

Shackleton, N.J., Berger, A., and Peltier, W.A., 1990. An alternative astronomical calibration of the lower Pleistocene timescale based on ODP Site 677. Trans. R. Soc. Edinburgh: Earth Sci., 81:251-261. Shipboard Scientific Party, 1995. Site 953. In Schmincke, H.-U., Weaver, P.P.E., Firth, J.V., et al., Proc. ODP, Init. Repts., 157: College Station, TX (Ocean Drilling Program), 317-394.

Sikes, E.L., Keigwin, L.D., and Curry, W.B., 1991. Pliocene paleoceanography: circulation and oceanographic changes associated with the $2.4 \mathrm{Ma}$ glacial event. Paleoceanography, 6:245-258.

Stein, R., 1985. Late Neogene changes of paleoclimate and paleoproductivity off Northwest Africa (DSDP Site 397). Palaeogeogr., Palaeoclimatol., Palaeoecol., 49:47-59.

Sverdrup, H.U., Johnson, M.W., and Fleming, R. (Eds.), 1947. The Oceans: Their Physics, Chemistry and General Biology: Englewood Cliffs, NJ (Prentice-Hall).

Tiedemann, R., Sarnthein, M., and Shackleton, N.J., 1994. Astronomic timescale for the Pliocene Atlantic $\delta^{18} \mathrm{O}$ and dust flux records of Ocean Drilling Program Site 659. Paleoceanography, 9:619-638.

Tiedemann, R., Sarnthein, M., and Stein, R., 1989. Climatic changes in the western Sahara: aeolo-marine sediment record of the last 8 million years (Sites 657-661). In Ruddiman, W., Sarnthein, M., et al., Proc. ODP, Sci. Results, 108: College Station, TX (Ocean Drilling Program), 241-277.

Tolderlund, D.S., and Bé, A.W.H., 1971. Seasonal distribution of planktonic Foraminifera in the western North Atlantic. Micropaleontology, 17:297329.

Tomczak, M., 1982. The distribution of water masses at the surface as derived from T-S diagram analysis int he CINECA area. In Hemple, G. (Ed.), The Canary Current: Studies of an Upwelling System, a Symposium held in Las Palmas. Rapp. Proc.-Verbaux des Réunions, Cons. Int. Explor. Mer, 180:48-49.

Tomczak, M., and Hughes, P., 1980. Three-dimensional variability of water masses and currents inthe Canary Current upwelling region. "Meteor" Forschungsergeb. -Ergebn. Reihe A, 21:1-24.

U.S. Naval Weather Service Detachment, 1976. Summary of Synoptic Meteorological Observations (SSMO) - West African and Selected Island Coastal Marine Areas, 1: Asheville, NC (U.S. Naval Weather Service), 238-316.

Van Camp, L., Nykjær, L., Mittelstaedt, E., and Schlittenhardt, P., 1991. Upwelling and boundary circulation of Northwest Africa as depicted by infrared and visible satellite observations. Prog. Oceanogr., 26:357-402.

Weaver, P.P.E., 1987. Late Miocene to Recent Planktonic foraminifers from the North Atlantic: Deep Sea Drilling Project Leg 94. In Ruddiman, W.F., Kidd, R.B., Thomas E., et al., Init. Repts. DSDP, 94: Washington (U.S. Govt. Printing Office), 703-727.

Zimmerman, H.B., Shackleton, N.J., Backman, J., Kent, D.V., Baldauf, J.G., Kaltenback, A.J., and Morton, A.C., 1984. History of Plio-Pleistocene climate in the northeastern Atlantic, Deep Sea Drilling Project Hole 552A. In Roberts, D.G., Schnitker, D., et al., Init. Repts. DSDP, 81: Washington (U.S. Govt. Printing Office), 861-875.

\footnotetext{
Date of initial receipt: 1 July 1996

Date of acceptance: 10 January 1997

Ms 157SR-106
} 


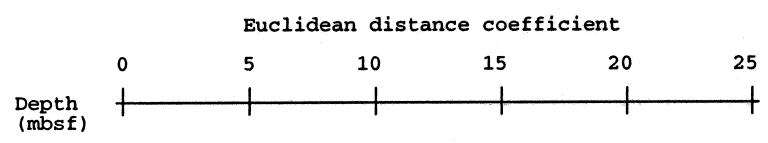

42.71

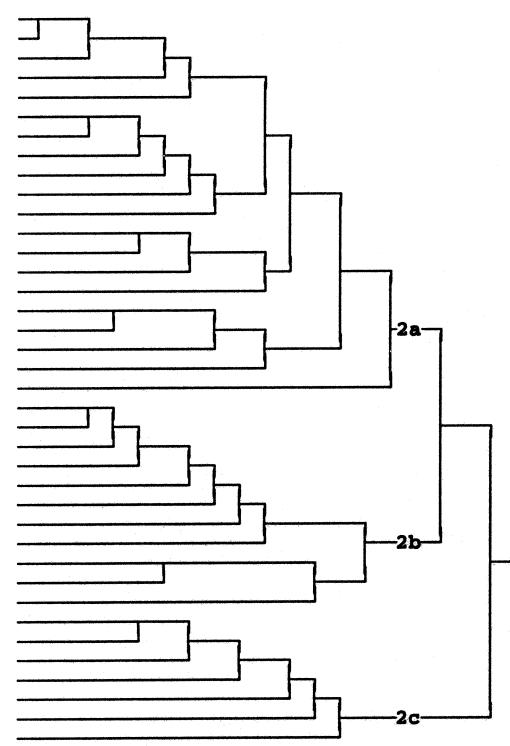

62.66

72.92

37.73

117.14

96.7

5.75

15.45

8.96

3.31

141.71

138.2

139.24

106.

115.57

104.48

118.27

92.27

85.80

122.04

127.13

161.15

176.2

169.16

159.60

235.06

13.15
68.73

84.23

81.27
144.76

33.48

53.76

55.05

28.96
43.71

6.67
18.41

25.89

1.30
36.22
90.71

90.71
65.03

149.01

128.80

154.49

157.79

147.3

151.10

132.22

83.38
121.22

82.14

109.30

109.38
94.28

108.01
41.10

41.10
81.19

74.51

77.42
110.49

112.11

99.74

167.82
136.50

131.30

164.15
135.06

218.81

218.81
195.50

200.2

187.72

192.60

226.00

207.41

245.11

180.3

198.57

206.47

216.28

174.18

184.80

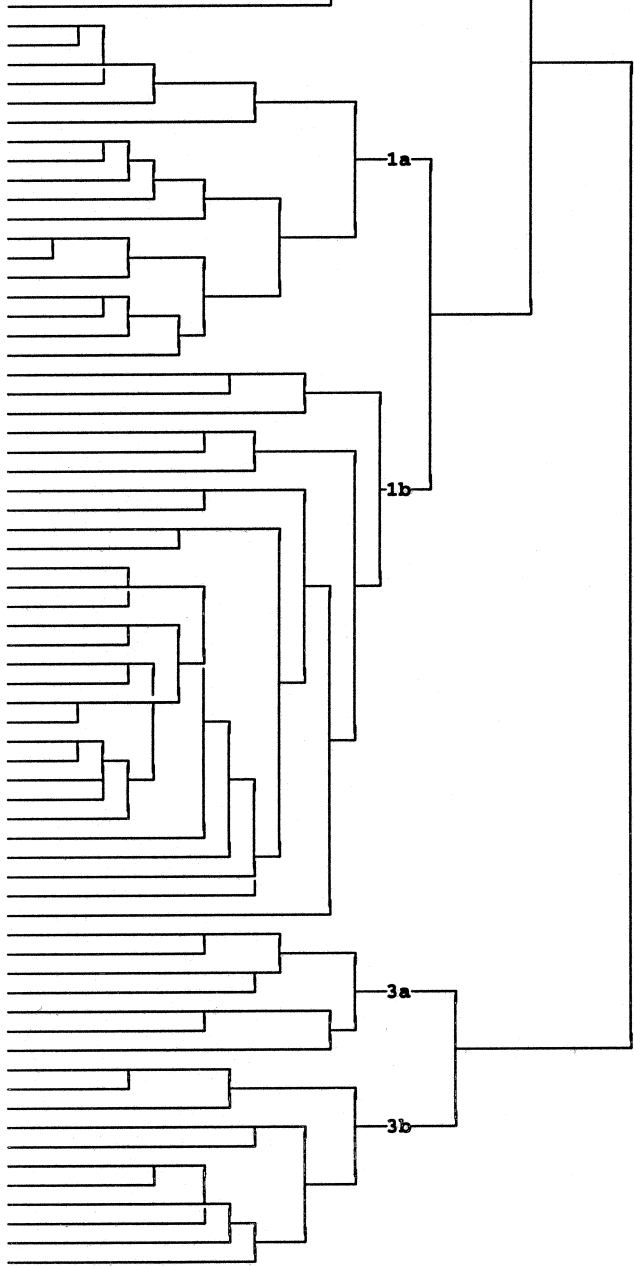

Figure 5. Dendrogram of Q-mode cluster analysis of 103 samples from Site 953. Three major clusters of samples are identified at the rescaled distance coefficient of 20, and seven subclusters are distinguished at the rescaled distance coefficient of 15. 


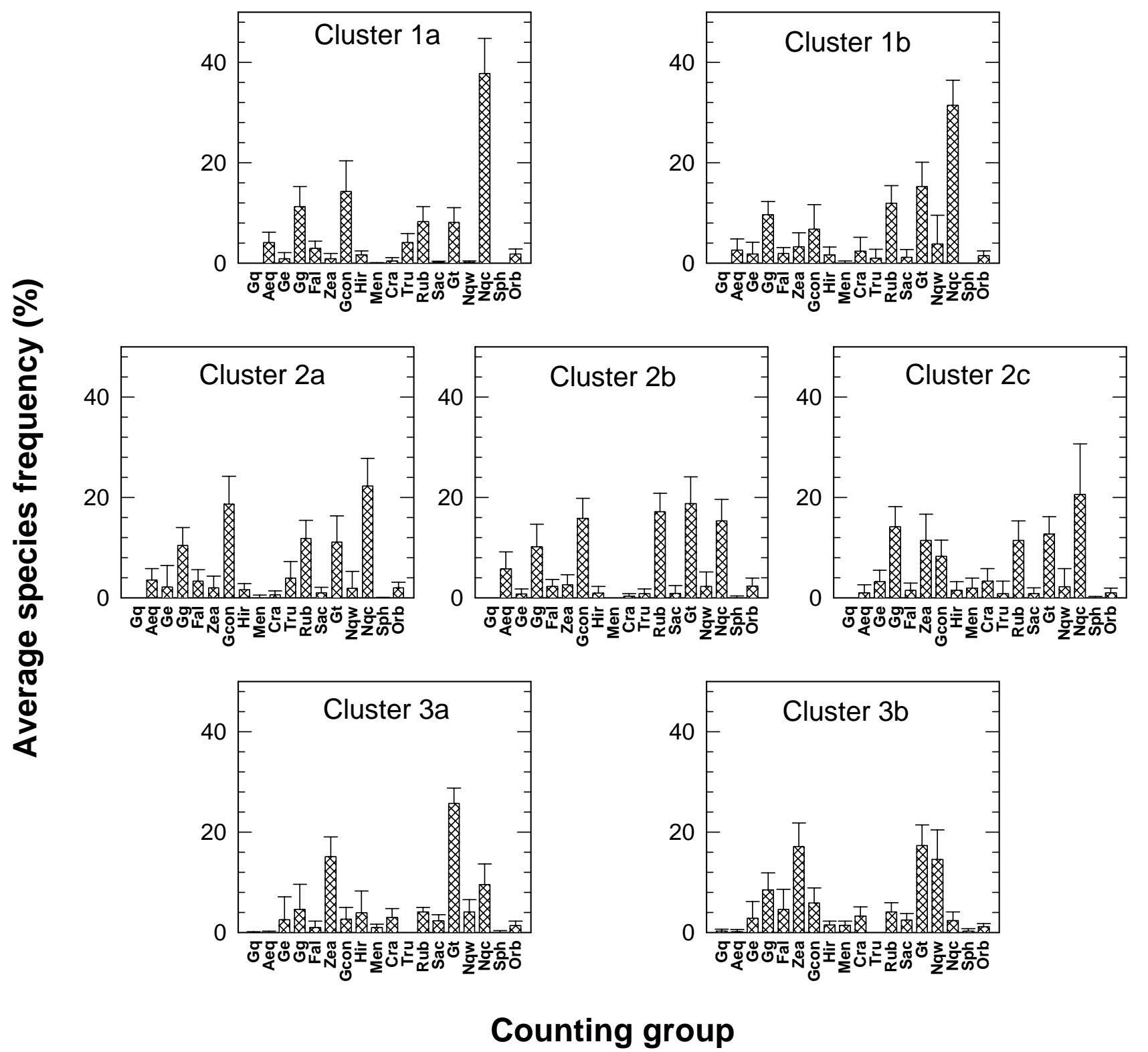

Figure 6. The average percentage of each counting group is shown within each subcluster. The environmental meaning of each subcluster is made based on the abundance of species and knowledge of their environmental preferences. 


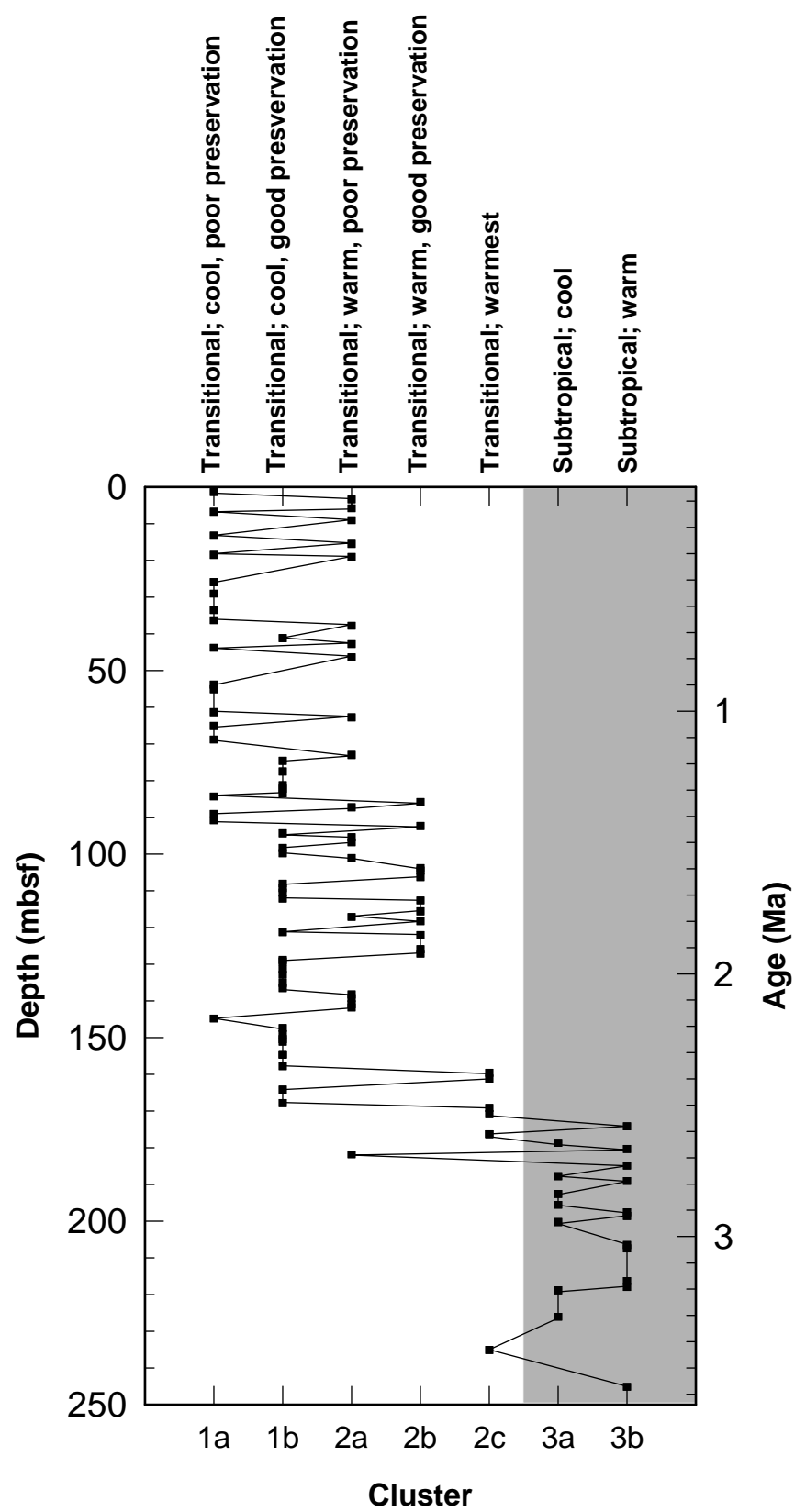

Figure 7. The cluster assignment of each sample is plotted vs. depth and age in Site 953. The clusters are arranged from coolest on the left to warmest on the right so that the plot clearly shows the cooling of surface waters from the late Pliocene to the latest Quaternary. 